\title{
イネ馬鹿苗病防除に関する研究
}

\section{I 。種もみ比重選の防除効果におよぼす影響}

\author{
北村 義 男* \\ Studies on the Control of Bakanae Disease of Rice Plant \\ I. Influence of the selection of rice seeds by specific gravity \\ upon the control of Bakanae disease.
}

\section{Yoshio Kitamura}

摘要 : イネ馬鹿苗病罹病もみの比重と発病との関係 ならびに比重選が薬剤消毒効果におよぼす影罯につい て試験を行い, 本病防除に対する比重選の効果を明ら かにしようとした.

種もみの比重別分布をみると. 比重1.15～1.25に含 まれるもみは自然感染のヤマビュが $88 \%$, マンリョウ が $83 \%$ で，人工接種の滋賀旭 27 号は $64 \%$ となり，いず れも比重1.25以上のもみはほとんどみられなかった。 3 品種とも種もみの比重が小さくなるにともなって不 発芽率が高くなり, 発病率拉よびもみがら, 玄米から の菌検出率も高くなる傾向を示した. 比重 $1.00 \sim 1.15$ の範团で種もみを選別播種しても, 水選だけの場合と

\begin{abstract}
緒 言
近年イネ馬鹿苗病の発生が多く全国的に注目を集め ているが，とくに箱育苗の普及にともなって年々増加 する傾向にあり, 種子伝染性病害の重要性が再認識さ れつつある、本病は罹病もみによって伝染, 発病する ため, 種もみ消毒は有力な防除手段であるが, 馬鹿苗 病菌は種もみの表面のみならず肧乳, 肧など組織の深 部への侵入率もかなり高くこのような種もみに対し ては, 従来の有機水銀剤では完全に防除することは困 難である1,2,4). ところで水稲栽培上, 種もみの比重選 は育苗技術の 1 つとして昔から重要視され, 稳実不良 もみを除去することによって, 馬鹿苗病をはじめ,ごま はがれ病, いもち病などの保菌もみの除去と発病防止
\end{abstract}

発病率がほとんど変らなかったが，これは分布率が高 い比重1.15以上のもみによって発病が大きく支配され るためである。一方種もみを各比重別にベンレート水 和剂の $500 \sim 4,000$ 倍液に 6 時間浸潰し消毒効果を調べ た結果, 低濃度浸漬でも種もみの比重が大きくなるに つれて, すぐれた効果を示し, 比重1.20 1.25の種も みでは4,000倍液でも500倍浸漬と大差なかった。

以上の結果から, 比重選によって発病を完全に抑え ることは期待できないが, 保菌もみをかなり除去でき るもので, とくに内部侵入菌の多い軽比重もみを除去 することによって消毒効果の向上をはかることができ るものと思われる。

\footnotetext{
* 滋賀県農業試験場
} 

の防除効果におよぼす影響

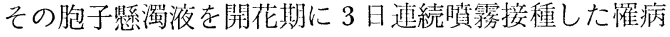
もみ，拉よび本病の多発生田から採集した自然感染も みを使用した，供試した種もみは下に示すとおりであ る.

（1）マンリヨウ：甲賀郡甲賀町産 (1970), 自然感染

（2）ヤマビコ：草津市川原町産（1971），自然感染

(3) 滋賀旭 27 号 : 滋贺農試産 $(1971,1972)$, 人工接 種

2. 種もみの比重区分

比重液は硫安を水道水に添加して $1.00,1.10,1.15$, $1.20 ， 1.25$ の 5 種類を調製した。 上記の䍜病乾もみを まず 1.00 比重液（水）に投入，沈下したもみはさら に 1.10 の比重液に投入した。これを順次くり返し，も みの浮沈によって各比重区分した後, 流水中で十分に 洗浄し供試した。

\section{試験方法および結果}

1. 䅜もみの比重分布

乾もみ $40 \mathrm{~g}$ を比重区分し，各区分ごとにもみを計数 し，全粒に刘する百分率を求めた，2回反復した平均 を示すと Fig. 1 のとおりである.

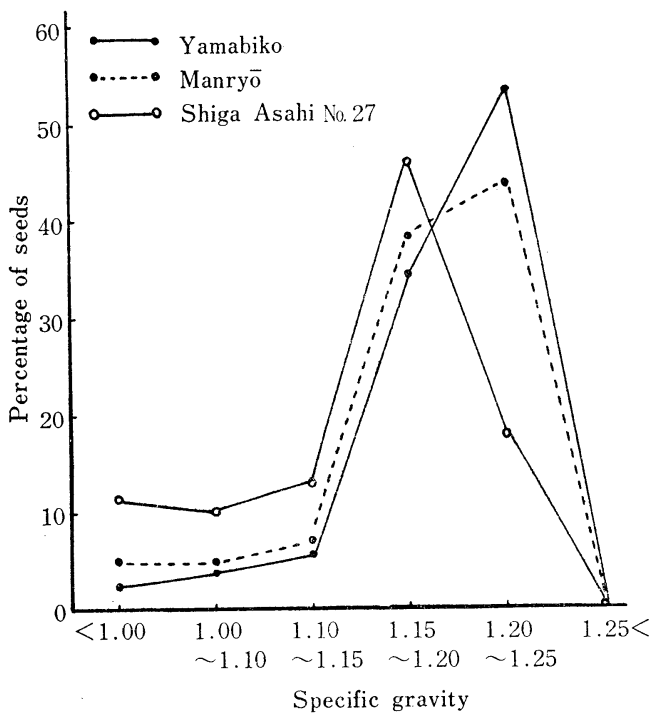

Fig. 1. Ripening grades expressed by specific gravity of rice seeds infected by Bakanae fungus.

ヤマビコ, マンリョウでは比重1.20〜 1.25 のもみ数 が最も多く，1.15１.25 の分布率はそれぞれ 88.1， $82.8 \%$ であった。一方人工接種した滋賀旭 27 号は比重 1.15〜1.20の分布率が最も高く, 1. 15〜 1.25のもみ数 は64.3\%で他の 2 品種に比べて少し低かった.したが
って比重 $1.00 \sim 1.15$ のもみ数はやや多く，1.00以下の 水に浮上したもみも多かった。供試した 3 品種では, 比重1.25以上のもみはほとんど涊められなかった。

2. 種もみの比重と保菌との関係

比重区分した種もみをもみがらと玄米に分離し，硫 酸ジヒドロストレプトマイシン $(300 \mathrm{ppm})+$ シ メチ ルクロロテトラサイクリン (100 ppm)混合液に 15～20 時間浸漬後，殺菌水で 2 回洗浄した。これを PCNB 水和剂 (75\%) 加用 PSA培地 ( $\mathrm{pH} 3.6)$ にシャーレ 当り 20 粒ずっ, $28^{\circ} \mathrm{C}$ に日間保った後, 菌の生育状 洗を調查し，菌そうの形状，色，鏡檢などにより馬鹿 苗病菌の検出を行った. 1 区 2 シャーレ, 2 回反復し た. 結果は Fig. 2, 3 のとおりである.

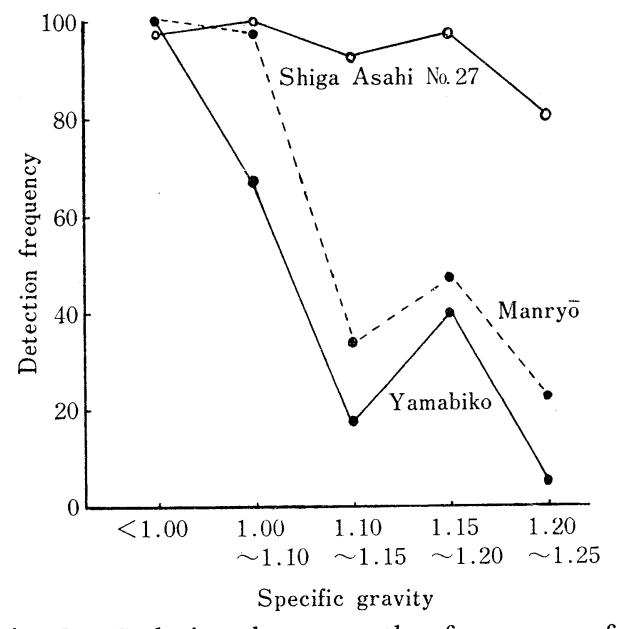

Fig. 2. Relation between the frequency of detection of Bakanae fungus in hulls and the specific gravity of rice seeds.

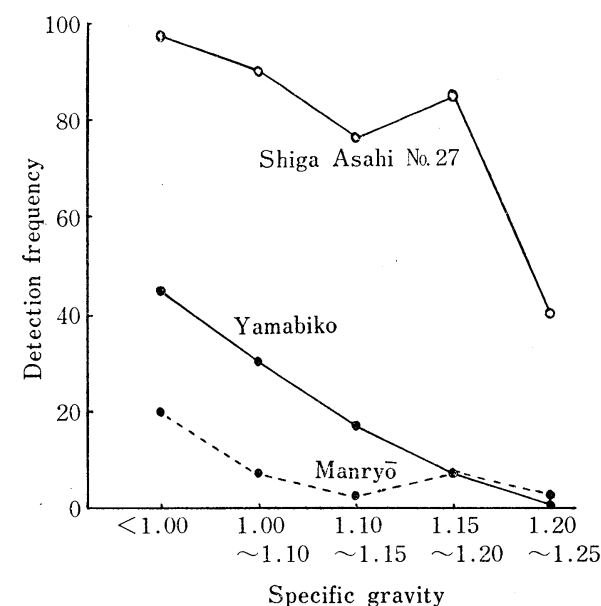

Fig. 3. Relation between the frequency of detection of Bakanae fungus in hulled rice and the specific gravity of rice seeds. 
滋賀旭 27 号 (人工接種) はもみがら，立米ともに菌 の検出率はきわめて高く, しかも比重1.20以下では比 重による検出率の差はほとんどなかった。しかし 1.20 以上になると検出率は下降し，とくに立米では極端に 低下した.これに対してヤマビュ,ママンリョウでは比

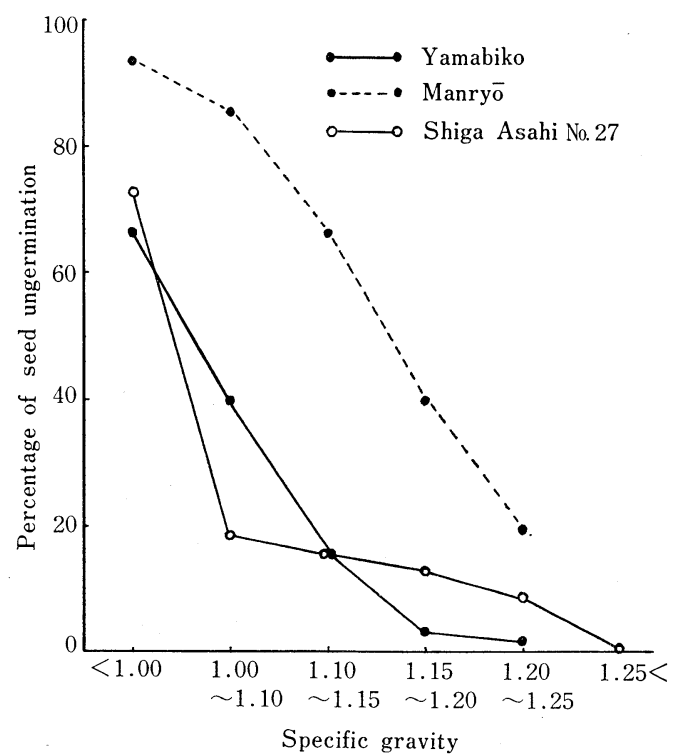

Fig. 4. Relation between the percentage of seed ungermination and the specific gravity of rice seeds.

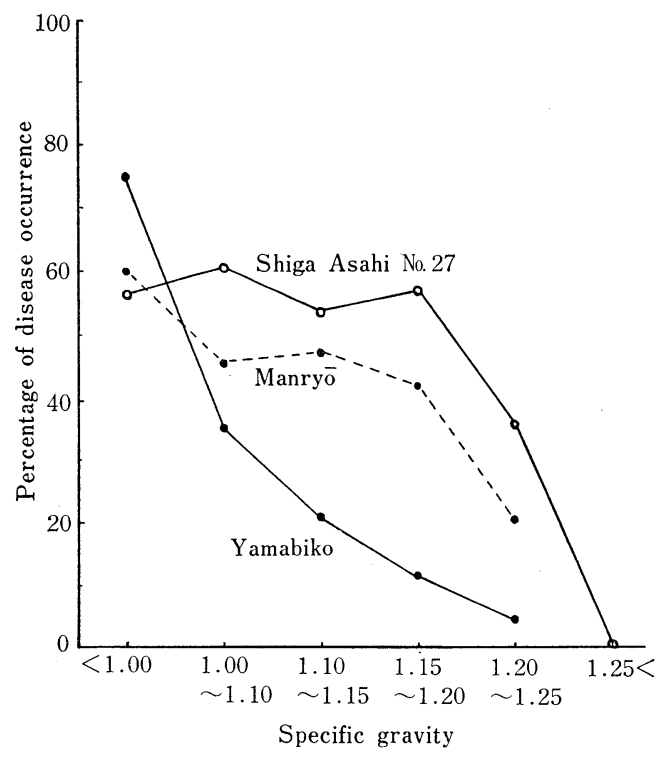

Fig. 5. Relation between the percentage of occurrence of Bakanae disease in seedlings and the specific gravity of rice seeds.
重が小さい種もみほど，もみがら，玄米いずれも菌の 検出率は高くなる傾问を示した.

3. 種もみの比重と発病との関係

1 で用いた種もみを各比重区分ごとにハト胸程度に 催芽した後，バット $(34 \times 28 \times 4 \mathrm{~cm})$ に播種しガラス 室内で育苗した: 用土にはバット当り, 細粒 $8 \cdot 6 \cdot 8$ 化成 $8 \mathrm{~g}$ を混合施用した。調查は徒長苗および枯死苗 （茎基部にカビがみられる）を 7〜10日ごとに抜き取 り, 病苗率, 不発芽率などを求めた。結果はFig. 4, 5 に示した.

種もみの比重と発芽との間には密接な関係が認めら れ， 3 品種とも比重が小さいほど不発芽率が高かった. 発病との関係についてみると, ヤマビコ, マンリョウ では種もみの比重が䁌すにつれて発病が減少する傾向 にあり，とくにヤマビコの発病率はほぼ直線的に低下 した. 一方滋賀旭 27 号の発病率は比重 1.20 以下の種も みでは大差なく，1.20以上になってはじめて低下した. これらの結果は 3 品種とも, 種もみの菌検出結果とほ ぼ同じ傾向である.

\section{4. 種もみ比重選と発病との関係}

種もみの比重と保菌ならびに発病との間には，かな り高い負の相関が認められるが, 実際に比重選を行う ことによって, どの程度保菌もみを除去し発病を抑え ることができるかを示したのが Fig. 6 である.

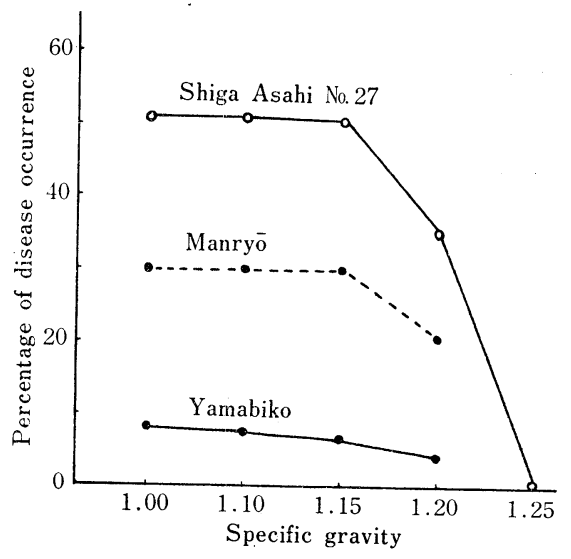

Fig. 6. Influence of selection of rice seeds by specific gravity upon the occurrence of Bakanae disease.

これによると 3 品種とも, 比重 $1.00 \sim 1.15$ 範囲で 選別, 播種を行っても発病率はほとんど変らず, 水 選のみで播種した場合と大差なかった。これに対して 1.20 以上の比重選を行えば発病をかなり軽減すること ができる. 
5. 種もみの比重と消毒効果との関係

滋賀旭 27 号 (人工接種) の乾もみ $240 \mathrm{~g}$ を比重区分 し，各区分ごとの種もみを流水中でよく洗浄した後, ほぼ 6 等分し，ルベロン 2,000 倍液に $2 ， 4 ， 8$ 時 間, またベンレート水和剤 $(50 \%)$ の 500，2,000，4,000 倍液に各 6 時間それぞれ浸漬した。ベンレート浸漬区

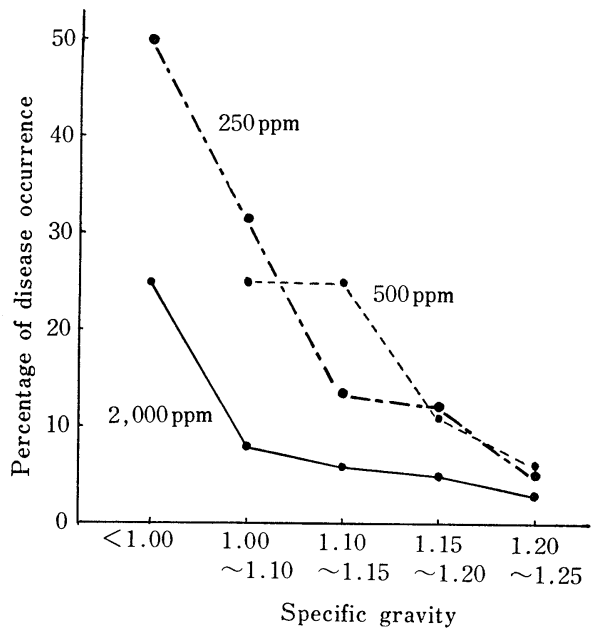

Fig. 7. Relation between the efficiency of disinfection of seed by soaking in Benlate suspension for 6 hours on Bakanae disease and the specific gravity of rice seeds, Shiga Asahi No. 27.

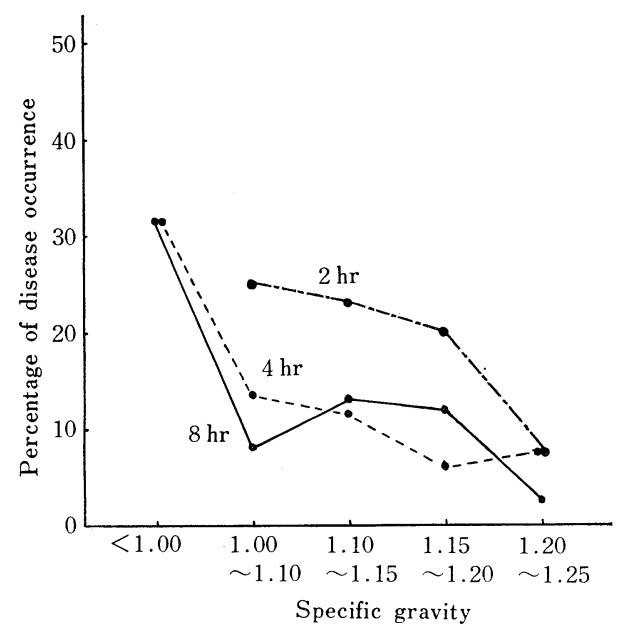

Fig. 8. Relation between the efficiency of disinfection of seed by soaking in $500 \mathrm{ppm}$ solution of Ruberon(EMP : $3.45 \%$ ) on Bakanae disease and the specific gravity of rice seeds, Shiga Asahi No. 27.
は八ト胸催芽もみを消毒後, 新聞紙上にひろげて半乾 し,ルベロン浸漬区とともに育苗箱に播種した（無肥 料), 育苗はガラス室内で行い徒長苗, 枯死苗を順次 拔き取って病苗率を調査した。結果は Fig. 7,8 のと おりである。

ベンレート区では種もみの比重が小さいほど各濃度 間の防除効果にかなりの差が認められ，500 倍に比へ て2,000，4,000倍など低濃度浸漬の効果が劣った。し かし比重1.15以上の種もみでは, その差は小さくなり， $1.20 \sim 1.25$ では各濃度とも効果はほとんど変らず, 低 濃度でも顕著な効果を示した。 ルベロンの場合は効果 に多少変動がみられるが, 比重1.20 1.25の種もみで は浸漬時間による差は小さく, いずれも高い効果を示 し, ベンレートとほぼ同じ傾向が認められた.

\section{考察}

イネ馬鹿苗病は種子伝染性病害であり。その防除は 従来から種もみ消毒の励行とともに, 比重選による稔 実不良の保菌もみ除去が強調されている，比重選は個 人育苗を対象とした比較的小規模経営では余り問題は ないが, 近年機械移植栽培の目ざましい普及発展にと もない，とくに大量育苗施設では種もみの処理量が多 く，作業能率や施設の面でも実施されにくい状況にあ る. 種もみの比重と発病について, 渡部 ${ }^{6)}$, 常楽ら ${ }^{3)}$ は比重が大きくなるにともなって発病率は低下すると しているが, いずれも各比重別種もみと発病との関係 について述べたもので, 比重選による実用的防除効果 や消毒効果向上にどの程度寄与するかについてはふれ ていない.一方松本 ${ }^{5)}$ は種もみの比重と発病との間に は密接な関係はみられないとし, もっぱら種もみ消毒 の必要性を強調している。

本試験で供試した罹病程度の異なる 3 品種の比重別 粒数分布をみると, 比重1.15 1.25の平均分布率はヤ マビコ $88.1 \%$ ，マンリョウ $82.8 \%$ ，人工接種した滋賀 旭 27 号では $64.3 \%$ であった。ただ滋賀旭 27 号は他の 2 品種に比べて, 比重1.15以下の分布率が高かったのは 病原菌を噴霧接種した影響がでているものと思われる. 種もみの比重と発芽とは密接な関係にあり, 比重が小 さいほど不発芽率が高く稔実不良もみが多いことを示 している. 発病との関係についても, 種もみの比重が 小さいと発病が多くなる傾向はヤマビコではきわわて 顕著であり, 他の 2 品種についても発病率に多少の変 動はあるがほぼ同じ傾向を示し, 比重1.00以下の水に 浮上した種もみでは不発芽率, 発病率がとくに高かっ 
た、またもみがら，玄米から菌の検出を行った結果， 比重が小さくなるほど検出率が高くなる傾向にあり， 発病の場合とほぼ一致した。したがって比重の小さい 種もみは稔実が悪く, 保菌率が高くて発病も多い. 比 重1.00以下の種もみは菌の検出率, 発病率ともに高い が, 実際に播種することはほとんどないからまず問題 ないとして，種もみを各比重別に投入し，浮上したも みは捨て, 沈下したもみ全部を播種すると, 比重 1.00 $\sim 1.15$ の選別では 3 品種とも比重選を省略し水選の 行った場合と発病率はほとんど変らず，1.20以上にな ってはじめて低下した：この原因は種もみの比重分布 や発芽率と関係があり, 比重が小さいと種もみの発病 率は高くなるが該当粒数が少なく, 発芽も悪いから全 体の発病に与える影響はきわめて小さく, むしろ粒数 割合の高い比重区分の発病に左右されるためである.

人工接種もみでも比重 1.15 以下のもみ数がそれほど多 くないことは注目されよう. 比重1.20以上では発病は かなり軽減されるものの, 効果は不十分であり, また 種もみの分布率が自然感染のヤマビコ, マンリョウで 約 $50 \%$, 滋賀旭 27 号では $18.3 \%$ とわめて低いことか ら, 必要種もみ量確保の面でも問題があり, 比重選だ けで発病を防止することは実際不可能である。

比重別種もみの消毒効果をみると, ベンレート 500 倍浸漬の防除効果は顕著であり，2,000，4,000倍の効 果は劣るものの比重 $1.15 \sim 1.20$ では雨濃度の効果は
500 倍に近くなり，1.20〜1.25 ではほとんど効果に差 がみられない。このことは病原菌が種もみ表面の比較 的浅い部分に侵入している污染程度の軽い種もみは $2,000,4,000$ 倍などの低濃度浸漬でも十分消毒効果を あげられることを示している。

これらのことから, 比重選だけで馬鹿苗病を完全に 防除することはむずかしく，種も消毒を行う必要が ある.一般に比重選の基準は1.10〜1.13になっている が，これだけでは馬鹿苗病に対する発病防止効果は期 待できない. しかし比重選を行って消毒効果のでにく い病原菌内部侵入もみを少しでも除去し, 防除価を高 めることは, 近年急速に普及拡大している箱育苗にお ける 2 次伝染》を防ぐ上からも重要である。

\section{引用文 献}

1) 古田力・山形 昇 (1960): 日植病報. $25: 59$

2）日野稔彦.古田力 (1968): 中国農試報. E 2 : 97 $-109$

3) 常楽武男・梅原吉広 (1974) : 今月の農薬. $3: 14$ $-17$

4) 中沢雅典 (1959): 愛知農試報. 15: 1-124

5) 松本和夫 (1971): 中国農業研究. $42: 19-20$

6）渡部茂 (1965)：北日本病虫研報。16：25-26

7) 渡部茂 (1971)：北日本病虫研報. $22: 66$

\section{Summary}

In order to clarify the valuation of selection of rice seeds by specific gravity for the control of Bakanae disease of rice plant, the relation between gravity of the ripening rice seeds and the occurrence of Bakanae disease in seedlings, and the effect of gravity selection on seed disinfection by chemicals, were investigated, using three varieties of rice plant infected by Bakanae fungus, Gibberella fujikuroi (Saw.) Woll., viz., Yamabiko, Manryō and Shiga Asahi No. 27. The seed of Shiga Asahi No.27 was inoculated with conidial suspension of the fungus at the flowering period. The ripening grade was divided into 6 classes according to specific gravity of a rice seed, ranging from 1.00 to 1.25 with an interval of 0.05 or 0.10 . Each class of rice seeds was sown in nursery bed. The mycelia in hulls and hulled rice were examined to clarify the degree of invasion of the fungus into seeds. On the one hand, the classes of the seeds were soaked separately in 250-2,000ppm suspension of Benlate wettable powder containing 50\% benomyl for 6 hours. The results were summarized as follows.

1. Percentage of rice seeds with 1.15 to 1.25 of specific gravity was $88 \%$ in Yamabiko, $83 \%$ in Manryo, and $64 \%$ in Shiga Asahi No. 27 which were inoculated. Very few seeds possessed specific gravity higher than 1.25 in any of three varieties of rice plant.

2. As the specific gravity of seeds decreased, the percentage of ungerminable seeds, occurrence of Bakanae disease, and detection of the fungus in hulls and hulled rice increased.

3. The seeds with 1.00-1.15 specific gravity resulted in the same degree of the disease occurrence 
の防除効果におよぼす影響

to the seeds with 1.00 specific gravity, indicating that the degree of disease occurrence of seeds were predominantly influenced by specific gravity higher than 1.15 .

4. The better disinfection effect of seed by soaking in different concentration of Benlate was given with the higher specific gravity of seeds. In the case of soaking seeds with specific gravity higher than 1.20 , Benlate at $250 \mathrm{ppm}$ gave good controlling effect about equally to that at $2,000 \mathrm{ppm}$.

5. From these results, it seemed that seed selection by specific gravity was not a perfect protective measure for Bakanae disease, it was, however, of use for increasing the efficiency of seed disinfection by eliminating the severely infected seeds. 